\title{
Using a Reconciliation Module Leads to Large Gains in Evolution Acceptance
}

\author{
John Lindsay, ${ }^{\dagger}$ Adhieu Arok, ${ }^{\dagger}$ Seth M. Bybee, ${ }^{\ddagger}$ Walter Cho, $\$$ \\ April Maskiewicz Cordero, $\$$ Daniel G. Ferguson, ${ }^{\dagger}$ Leontine L. Galante," \\ Richard Gill, ${ }^{\dagger}$ Mark Mann," Steven L. Peck, ${ }^{+}$Cassidy L. Shively, ${ }^{\dagger}$ Michael R. Stark," \\ Joshua A. Stowers, ${ }^{\dagger}$ Michael Tenneson, ${ }^{\circledR}$ Ethan R. Tolman, ${ }^{* *}$ Thomas Wayment, ${ }^{\dagger+}$ \\ and Jamie L. Jensen ${ }^{\text {t* }}$ \\ 'Department of Biology, "Department of Biology, Monte L. Bean Museum, "Department of \\ Physiology and Developmental Biology, **Department of Plant and Wildlife Sciences, and \\ ${ }^{ }$Comparative Arts and Letters, Brigham Young University, Provo, UT 84602; \$Department of \\ Biology and "School of Theology and Christian Ministry, Point Loma Nazarene University, San \\ Diego, CA 92106; "School of Science and Engineering, Colorado Christian University, Lakewood, \\ CO 80226; @ Department of Natural and Applied Sciences, Evangel University, Springfield, MO 65802
}

\begin{abstract}
Too many students reject the theory of evolution because they view it as incompatible with their religious beliefs. Some have argued that abandoning religious belief is the only way to help religious individuals accept evolution. Conversely, our data support that highlighting faith/evolution compatibility is an effective means to increase student acceptance. We surveyed students enrolled in entry-level biology courses at four religiously affiliated institutions. At each university, teachers gave students a presentation that demonstrated potential compatibility between evolution and faith within the teachings of each university's respective religious affiliation. Students were asked to evaluate their own beliefs about evolution both before and after this instruction. After instruction at each university, students showed significant gains in evolution acceptance without abandoning their religious beliefs. These results demonstrate that giving religious students the opportunity to reconcile their religious beliefs with the theory of evolution under the influence of intentional instruction on the compatibility of belief and evolution can lead to increased evolution acceptance among religious students.
\end{abstract}

\section{INTRODUCTION}

From the perspective of some faith traditions, there is perhaps no greater cause of tension between faith and science than the theory of evolution. This tension has been highlighted in various court cases over the past century and by certain religious activists protesting its inclusion in public school curricula (Hall and Woika, 2018). Recent polls have also shed light on the tension. In a 2017 survey, nearly 38\% of Americans responded that they still believe God created humans in their current state within the last 10,000 years (i.e., young Earth creationism; Gallup, 2017). This number is high compared with other developed countries such as Greece (29\%; Pew Research Center, 2016), Russia (26\%; Pew Research Center, 2016), the United Kingdom (9\%; YouGov, 2017), and Canada (15\%; YouGov, 2017). In the United States, a number of solutions have been proposed to address the problem of widespread rejection of evolution in religious populations. This paper discusses several approaches and then presents a promising solution to this persistent problem from the perspective of researchers teaching evolution in religiously affiliated institutions.

Teaching That Evolution Rejection Is a Product of Ignorance The first commonly used approach to evolution instruction is to view the conflict between religion and science with a "deficit model," arguing that a lack of acceptance
Peggy Brickman, Monitoring Editor Submitted Apr 29, 2019; Revised Aug 28, 2019; Accepted Sep 13, 2019

CBE Life Sci Educ December 1, 2019 18:ar58 DOI:10.1187/cbe.19-04-0080

*Address correspondence to: Jamie L. Jensen (jamie.jensenabyu.edu).

(c) 2019 J. Lindsay et al. CBE-Life Sciences Education (๑) 2019 The American Society for Cell Biology. This article is distributed by The American Society for Cell Biology under license from the author(s). It is available to the public under an Attribution-Noncommercial-Share Alike 3.0 Unported Creative Commons License (http://creativecommons.org/licenses/ by-nc-sa/3.0)

"ASCB®" and "The American Society for Cell Biology $\otimes^{\prime \prime}$ are registered trademarks of The American Society for Cell Biology. 
of evolutionary theory is simply a result of a deficit of understanding or inadequate reasoning ability (e.g., Lawson and Weser, 1990; Honey, 2015). Unfortunately, weakly supported claims that rejection is a product of low subject aptitude continue to propagate this simplistic deficit argument (Mead et al., 2017), and highly recognized evolutionary biologists, most notably Richard Dawkins (1989), polemically employ this view: "It is absolutely safe to say that if you meet somebody who claims not to believe in evolution, that person is ignorant, stupid or insane" (p. 34). Anecdotally, our experience has shown that such polemical statements are unproductive in changing attitudes toward acceptance of evolution.

\section{Teaching Students the Facts}

The second common approach promotes the idea that educating students and teachers about the facts of evolution would directly correlate with a resolution toward acceptance, that is, a "resolution model" (e.g., Alles, 2001; Cherif et al., 2001; Farber, 2003; Legare et al., 2013; Yerky and Wilczynski, 2014). The results of research on this approach are conflicting and complicated. Some studies have indicated a positive correlation between knowledge and acceptance (e.g., Johnson and Peeples, 1987; Rutledge and Warden, 2000), while others indicate there is no correlation (e.g., Bishop and Anderson 1990; Brem et al., 2003; Sinatra et al., 2003; Nehm and Schonfeld, 2007; Chinsamy and Plagányi, 2008; Hasan and Donnelly, 2011; Mead et al., 2017). In one study, once demographic characteristics including religion and political ideology were controlled for, educational attainment was not a factor in evolution rejection (Miller et al., 2006; Hill, 2014). However, four recent and robust studies have suggested a well-supported positive relationship between knowledge and acceptance (e.g., Rissler et al., 2014; Glaze et al., 2015; Dunk et al., 2017; Weisberg et al., 2018).

While the data are inconclusive, it is reasonable to assume that knowledge plays some kind of interactive role in the acceptance of evolution. Although a good starting point, and likely a necessary precursor to increasing acceptance, focusing only on knowledge of evolution may not be sufficient to increase acceptance among religious individuals. The relationship between knowledge and acceptance appears to be influenced by a number of other external factors, including religion, making it a multifaceted issue. Religious beliefs and background (Dagher and BouJaoude, 1997; Miller et al., 2006; Deniz et al., 2007), views about the nature of religion (Winslow et al., 2011), and pressure from parents (Winslow et al., 2011) influence one's views of evolution. In fact, several studies agree that those who hold a literal interpretation of scripture are more likely to reject evolution (Berkman and Plutzer, 2010; Baker, 2013; Hill, 2014).

\section{Emphasizing the Nature of Science}

Another approach to increase acceptance of evolution is to focus on helping students develop a clear and precise understanding of the nature of science. According to the National Science Teachers Association, "Science is characterized by the systematic gathering of information through various forms of direct and indirect observations and the testing of this information by methods including, but not limited to, experimentation. The principal product of science is knowledge in the form of naturalistic concepts and the laws and theories related to those concepts" (see www.nsta.org/about/positions/natureofscience .aspx). Using this approach has generally proven effective in helping students increase both their understanding and acceptance of evolution (e.g., Cavallo and McCall, 2008; Cofré et al., 2017; Dunk et al., 2017). Thus, teaching an understanding of how science is conducted, and what it can and cannot explain, is an excellent starting point for increasing acceptance.

\section{Offering a Reconciliation of Religion and Evolution}

Although emphasizing the nature of science has been shown to be generally effective at promoting acceptance, religious students/individuals in particular still often perceive evolution acceptance as something opposed to faith claims (Lamoureux, 2008). This is exacerbated by the disparity between the religious beliefs of biology educators and those of students. Only $\sim 10 \%$ of evolutionary biologists self-report as religious (Graffin and Provine, 2007), while $80 \%$ of the American population reports a belief in God (Pew Research Center, 2017). Clearly there is a potential disconnect between educators and their audiences' religious beliefs. This disconnect is also manifest in studies that show that an individual's religiosity-strong religious feeling or belief-is the most predictive factor of evolution acceptance (Dagher and BouJaoude, 1997; Hill, 2014; Rissler et al., 2014).

One recent review offers ways to remedy this divide by outlining six steps of "cultural competence" that can help educators better teach evolution to religious students without undermining religiosity (Barnes and Brownell, 2017). Their religious cultural competence in evolution education (ReCCEE) framework is grounded in existing research (see Table 2 of their paper for the literature base), and promotes six practices: 1) Acknowledge that some students may see a conflict between evolution and their religious beliefs. 2) Discuss and encourage the exploration of students' personal views on evolution and religion. 3) Explain to students the bounded nature of science and different ways of knowing. 4) Explain that there are diverse viewpoints on evolution and religion and that viewpoints are not restricted to atheistic evolution and special creationism. Discuss the possibility of theistic evolution. 5) Highlight religious leaders and biologists who accept evolution. 6) Explicitly discuss the potential compatibility between evolution and religion. We build on Barnes and Brownell's study, specifically step 6, which encourages professors to use potential compatibility to help religious students come to accept evolution. This method (hereafter referred to as the "reconciliation module") centers on educators providing religious students with potential religionspecific compatibility links between their respective religions and the theory of evolution. We suggest that this method will lead to a significant increase in student acceptance of evolution without diminishing an individual's religious conviction. We echo the words of biologist E. O. Wilson, a two-time Pulitzer Prize winner, "Science and religion are the two most powerful forces in the world. Having them at odds ... is not productive" (PBS, 2007).

\section{MATERIALS AND METHODS Informed Consent}

Permission for this study was obtained from each institution's institutional review board. Students were informed of the research and gave their consent to participate. 


\section{Sample Population}

Students were recruited from four religiously affiliated institutions for this study: Brigham Young University (BYU; affiliated with the Church of Jesus Christ of Latter-day Saints), Point Loma Nazarene University (PLNU; affiliated with the Church of the Nazarene), Colorado Christian University (CCU; an interdenominational Christian university), and Evangel University (EU; affiliated with the Assemblies of God). BYU is a private institution located in the western region of the United States and founded in 1875. It has a total undergraduate enrollment of 31,233 with an average grade point average (GPA) of 3.86 and an average American College Testing (ACT) score of 28.8 for incoming freshmen. PLNU is a private Christian liberal arts institution, founded in 1902 and also located in the West. It has a total undergraduate enrollment of 3150 with an incoming freshman average GPA of 3.79 and an average ACT score of 26. CCU is a private institution located in the West. It has an undergraduate enrollment of 1393 with an average GPA of 3.68 and an average incoming freshman ACT score of 25. EU is a private comprehensive Christian university founded in 1955 and located in the Midwest. It has a total undergraduate enrollment of 1,631 with an average GPA of 3.34 with an average incoming freshman ACT score of 23.

\section{Student Selection}

These universities were selected due to the majority of students having religious backgrounds and a willingness of faculty to participate in the study. Students were enrolled in introductory biology courses that included both majors and nonmajors. This study was conducted during the Fall 2017 and Spring 2018 semesters. At each institution, varying numbers of students participated, depending on how the instructor incentivized the surveys (see Table 1). Unfortunately, at some institutions, like CCU, incentive was low, attrition rates from the course were high, and the post quantitative instrument administration was delayed. Low response rates were likely due to a lack of incentive or simply a lack of time on the part of the students, but it is also a possibility that the CCU sample is biased: that is, those who had something negative to say were most likely to respond. As such, the remaining survey results were deleted from the quantitative analysis, although essay results were maintained.

\section{Reconciliation Modules}

In October 2017, BYU held a Roads to Reconciliation workshop bringing together four teams from the four religiously affiliated institutions. Teams consisted of a university theologian or scholar of religion, a university biologist, and a local community pastor. During the workshop, each team discussed (where materials already existed) or designed (where materials did not previously exist) reconciliation modules that showed compatibility between respective church doctrine and evolutionary theory and adapted them specifically to each university's religious affiliation. The duration of each module and exactly what should be included were not prescribed. Some schools chose to create a 1-hour classroom-based module, while others developed a variety of shorter activities for both the classroom and as homework spread out over the entire evolution unit. Each unique implementation is described in the following sections; however, the common focus for each module was providing compatibility possibilities between their respective religions and the theory of evolution.

The National Center for Science Education (NCSE; 2019) provides a continuum of possible religious and philosophical beliefs toward evolution and creation, including an explanation of the various positions. The five most common positions are briefly defined here. Young Earth creationists (YEC) "reject the conclusions of modern physics, astronomy, chemistry, and geology concerning the age of Earth, and they deny biological descent with modification. Earth, in their view, is between 6000 and 10,000 years old" (NCSE, 2019). Old Earth creationists (OEC) "accept most of modern physics, chemistry, and geology," acknowledging the scientific consensus about the age of the Earth, but most reject large-scale biological evolution and human evolution. Theistic evolutionists (TEs) "accept all the results of modern science, in anthropology and biology as well as in astronomy, physics, and geology," including human evolution. Their theological belief is that God creates through the laws of nature. Agnostic evolutionists accept all of the results from modern science, but claim that science cannot prove anything about God's existence. Alternately, atheistic evolutionists argue that science can provide an explanation for everything there is to know, and thus science proves there is no God (Dawkins, 2008; Taylor, 2019).

\section{BYU Module}

Denominational Information. BYU is affiliated with the Church of Jesus Christ of Latter-day Saints. Although the church has had a somewhat undulating history of influential religious leaders split on their opinions about evolution (for a review, see Evenson and Jeffery, 2005), the official teaching on evolution is neutral: "The Church has no official position on the theory of evolution ... Nothing has been revealed concerning evolution" ("What Does the Church Believe about Evolution?," 2016, p. 41). However, due to prominent religious authorities sharing conflicting opinions over the years, a majority of church members reject the theory (51\% rejected human evolution as of 2014; Pew Research Center, 2014).

TABLE 1. Response rates from each institution ${ }^{a}$

\begin{tabular}{lccccc}
\hline & $\begin{array}{c}\text { Total } \\
\text { enrollment }\end{array}$ & $\begin{array}{c}\text { Completed } \\
\text { pre surveys }\end{array}$ & $\begin{array}{c}\text { Have matched pre/ } \\
\text { post surveys }\end{array}$ & $\begin{array}{c}\text { Have matched pre/ } \\
\text { post essays }\end{array}$ & $\begin{array}{c}\text { \% Full participation survey/ } \\
\text { essays }\end{array}$ \\
\hline BYU & 144 & 117 & 75 & 101 & $52 / 70$ \\
PLNU & 66 & 66 & 59 & 47 & $89 / 71$ \\
CCU & 120 & 25 & - & 46 & $-/ 38$ \\
EU & 29 & 29 & 157 & 23 & $79 / 79$ \\
TOTAL & 359 & 237 & 217 & $44 / 60$ \\
\hline
\end{tabular}

aBYU, Brigham Young University; PLNU, Point Loma Nazarene University; CCU, Colorado Christian University; EU, Evangel University. 
Major Objective. The major focus of the reconciliation module at BYU is to help students become familiar with the church's official statements that there is no doctrine dismissing evolution.

Methodology. The module was conducted in class during a 50-minute lecture period directly before the evolution unit. We provided students with a copy of all official declarations of the church on evolution and human origins (referred to as the Evolution Packet, it can be accessed at BYU's Biology website: https://brightspotcdn.byu.edu/0d/ cc/3094a8654f60b552fa97c3df9999/evolution-packet.pdf). We then allowed the students time to consider and then discuss what the scriptures say about creation, emphasizing a figurative interpretation, and how this could potentially be compatible with the scientific account of evolution, including that of humans, allowing for openness and consideration of flexible viewpoints (e.g., on human origins). The presentation was given in a faith-friendly atmosphere by faculty who are members of the faith.

\section{PLNU Module}

Denominational Information. PLNU is affiliated with the Church of the Nazarene, which embraces a doctrine of scripture allowing a wide breadth of interpretations regarding the relationship between scripture and scientific teachings, including evolution. For decades, science and theology faculty alike have been provided great freedom to teach evolution, including human evolution, and affirm its continuity with Christian faith. However, the majority of the students come from church backgrounds averse to such reconciliation.

Objectives. The introductory biology courses have been implementing strategies for students to reconcile evolution and faith for many years. The goal is to expose students to multiple perspectives on the relationship between scripture and creation, and to enhance their appreciation for the broad spectrum of positions a Christian can hold.

Methodology. The module spanned the length of the evolution unit with the brief reconciliation activities introduced both in class and as homework. Before the beginning of instruction on evolution, the students read excerpts from the book Origins (Haarsma and Haarsma, 2011), which allows the class to enter a discussion with everyone at a similar starting point, understanding that there are various positions people can hold. After the instructor shares his or her own personal story reconciling evolution and faith, the module incorporates reading, writing, and discussion assignments that explore aspects of this conversation. These assignments are designed to help students cultivate humility and charity toward others and alternate positions. Our theology faculty teach their courses in Bible and Christian tradition in ways that seek to support and build on the goals of the biology faculty.

\section{CCU Module}

Denominational Information. CCU is an interdenominational Christian university whose philosophy, while broadly evangelical, seeks to nurture and develop each individual student's personal Christian faith. Included in the 13 university-wide strate- gic priorities are to "teach students how to learn, teach students to think for themselves, and to be a magnet for outstanding students and prepare them for positions of significant leadership" (www.ccu.edu/About/strategic-priorities/). CCU does not have an official position on evolution or the pedagogy thereof.

Objectives. The university provides ample exposure to the multitude of positions on evolution. This is done through a lecture series that is held roughly once every 4 years in which speakers representing a spectrum of positions toward the diversity of life on Earth present to students, faculty, staff, and the general public.

Methodology. Within the School of Science and Engineering, science majors are exposed to the concepts of evolution during their freshman year through the introductory biology courses Biological Principles and, subsequently, Biological Diversity. As an exclusively Christian faculty, during the introductory courses, instructors teach predominantly that theistic evolution and Christian faith are not mutually exclusive, while allowing room for discussion within this Christian framework. The reconciliation module served as an invaluable way to help open the door for discussion among these freshmen who had recently matriculated from a vast range of Christian backgrounds. It was taught directly before the evolution unit at the beginning of the semester.

\section{EU Module}

Denominational Information. EU is the national university of the Assemblies of God. While a stance on evolution is not a core doctrine of the denomination, a creation position paper was revised in 2010 and 2014 (https://ag.org/Beliefs/Topics -Index/The-Doctrine-of-Creation). This paper states, "Any evolutionary theory, including theistic evolution/evolutionary creationism, that claims all forms of life arose from a common ancestry is thereby ruled out." However, Assemblies of God constituents hold diverse views on evolution (Tenneson and Badger, 2010). About half align with YEC, about a fourth to a third align with OEC, and about 15\% align with TE. Very few hold an agnostic evolution or atheistic evolution view.

Objectives. Integration of faith, life, and learning is a core value at EU. Consequently, students study origins from theological, philosophical, and scientific perspectives simultaneously. In the module, students were taught that deistic and atheistic evolution constructs clearly lie outside the domain of biblically conservative Christianity (affirmation of biblical infallibility and inspiration). On the other hand, YEC, OEC, and evolutionary creation are embraced by Christians who hold a high view of scripture. While natural selection and subsequent evolutionary outcomes (a.k.a. microevolution) are not contested by informed members of this group, macroevolution and human evolution are. Students explore the reasons for this and are provided with examples of conciliatory approaches.

Methodology. The module began with a discussion of datadriven decision making and civility. Civil discourse was modeled from the beginning of the course in an attempt to make the classroom environment a safe one to discuss potentially inflammatory topics. The reconciliation module took place over the first six classroom periods, based largely on the book Christian Perspectives on Origins (Badger and Tenneson, 2014). Students 
also read and critiqued Gould's "Nonoverlapping Magisteria," or NOMA (Gould, 1997). Multiple class periods were spent exploring mainstream evolutionary theory and animal taxonomy. When applicable, references were made to reconciliation module components studied earlier in the semester.

\section{Experimental Design}

To determine the effects of our reconciliation modules, we gathered data before and following implementation in the classroom. We used both qualitative (essays) and quantitative (surveys) methods to gauge acceptance. In addition to determining changes in acceptance, data from the preinstruction instruments allowed us to identify potential predictors of initial acceptance and of a change in acceptance with reconciliation.

\section{Instruments}

Demographic and Opinion Survey. For determining predictors of evolution acceptance and change, a survey was created and administered before intervention. Items included age, geographic location in childhood, gender, religious affiliation, chosen major (science, technology, engineering, and mathematics [STEM] or non-STEM), whether a student received public or private schooling in high school, the degree to which a student interpreted the biblical Genesis narrative as a literal or figurative event, the extent to which evolution was covered in a student's high school, and a student's reaction to his or her high school instruction (the instrument can be found in the Supplemental Material).

Predictors from Survey. Two predictors from the survey were statistically significant and are described here: interpretation of Genesis and reaction to the teaching of evolution in high school. Respondents were given five options for the interpretation of the "six days of creation" in the book of Genesis: 1) They are six consecutive 24-hour days. 2) They are six 24-hour days with gap(s) of time. 3) They are six periods of time of unknown length. 4) They are six figurative days, not to be understood as real periods of time. 5) I am not sure. For analysis purposes, a response of 1 was coded as a "literal" interpretation of Genesis. Responses of 2 and 3 were considered semiliteral, in that respondents were allowing for some figurative interpretation. A response of 4 was considered a "figurative" interpretation of Genesis. Any response of 5 was eliminated from analysis.

For the other predictor, reaction to the teaching of evolution in high school, respondents were given six options: 1) It was not taught in my high school. 2) Acceptance without conflict. 3) Concern about the validity of evolution. 4) Feelings of mild conflict. 5) Feelings of severe conflict leading to rejection of evolution. 6) Feelings of neutrality; no strong reaction either way. Any response of 1 was eliminated from analysis. The remaining responses were ordered as follows: 3 and 5 as rejection or dismissive responses, 4 as mild conflict, 6 as neutral, and 2 as acceptance. None of the other variables measured in the survey were significant predictors.

Essays. In addition to the surveys, we administered essay prompts before and after the intervention. The first essay prompt asked students to reflect on their current, individual opinions about evolution. They were asked to define evolution and discuss the emotions and feelings that the word "evolution" evokes in them. They were also asked to explain how they have come to their current viewpoint. They were given a target of $\sim 500$ words. The second essay prompt asked them to re-evaluate what they had written in the first prompt and to comment on if and how their opinions of evolution had changed over the convening time since the first prompt. Again, they were given a target of $\sim 500$ words.

BYU, PLNU, and one instructor at CCU administered prompt 1 at the start of the evolution unit and prompt 2 at the end of the semester. The other instructor at CCU administered prompt 1 just before the module and prompt 2 just after. EU administered prompt 1 at the beginning of the semester and prompt 2 directly after the evolution unit. The timing of prompt 2 differed between institutions due to the nature of the module (whether it was one class period or spread out within the evolution unit) and convenience of sampling times within the curricula. While some students may have been given additional time to contemplate reconciliation, we do not believe this affected results of reconciliation, given that all evolution content was taught between prompts. Each instructor sent his or her students' essays to a single research team at BYU for coding. The coding team consisted of multiple authors, including a professor, J.L.J., a $\mathrm{PhD}$ student, D.G.F., and several undergraduate students, J.L., A.A., C.L.S., and E.R.T.

To code essays, the research team used previously established essay codes (see Bradshaw et al., 2018) and spent several weeks together reading essays and coding them into several different categories until interrater reliability surpassed 90\%. Researchers looked for overall themes from each student's response to code the essays into the most appropriate category. Many essays displayed multiple themes; in such cases, the most prominent theme was chosen. Codes for essay prompt 1 with sample quotations are shown in Table 2. Two additional codes were added to essay prompt 2 (13 and 14; see Table 3 ) to accommodate two additional common essay responses from the present study. For analysis purposes, these 13 codes were grouped into four categories: full acceptance (11 only), limited acceptance (7 and 12), rejection $(2-4,6)$, and other $(1,5$, $8-10,13)$. Codes and sample quotes for essay prompt 2 are shown in Table 3. Again, for analysis purposes, these 14 codes were grouped into four categories: full acceptance $(1,6,12)$, limited acceptance $(2,7,13,14)$, rejection $(4,8)$, and other $(3,5,9-11)$. Full acceptance refers to any response in which the student expressed an acceptance of evolution with no indication of any rejection of individual components (e.g., human evolution). Note, however, that, if a student did not mention human evolution in the essay (i.e., we are unaware of the student's acceptance or nonacceptance of this particular point), the student could still be coded as a "full acceptor." Thus, it is possible that the category is an overestimation of acceptance. However, given the open-ended nature of the essay prompt, this was unavoidable. As seen in the codes in Tables 2 and 3, limited acceptance referred to any response in which students acknowledged that evolution occurs but took specific issue with one or more components of the theory (most common components included human origins and speciation events or macroevolution).

Quantitative Measure of Evolution Acceptance. We used the Generalized Acceptance of EvolutioN Evaluation, or GAENE (Smith et al., 2016), as a quantitative measure of the 
TABLE 2. Essay prompt 1 codes

\begin{tabular}{|c|c|c|c|}
\hline Code & Brief description & Example quote & Final coding \\
\hline 1 & $\begin{array}{l}\text { Discomfort: fear, discomfort, } \\
\text { confusion }\end{array}$ & $\begin{array}{l}\text { "It's confusing to me to think of us once being little cells floating around and then } \\
\text { becoming people who can think and talk and do so many things." }\end{array}$ & Other \\
\hline 2 & $\begin{array}{l}\text { Demeaning: the idea is repugnant } \\
\text { or offensive }\end{array}$ & "When I hear the word evolution I cringe. I absolutely hate the word evolution." & Rejection \\
\hline 3 & $\begin{array}{l}\text { Improbable: the idea cannot be } \\
\text { true }\end{array}$ & $\begin{array}{l}\text { "The word that first pops into my head when I think about evolution would be } \\
\text { fake/false." }\end{array}$ & Rejection \\
\hline 4 & $\begin{array}{l}\text { Religious conflict: rejection for } \\
\text { religious reasons }\end{array}$ & $\begin{array}{l}\text { "Although I don't think evolution and Christianity can coexist, I do believe that it } \\
\text { is important to learn about both ends of the spectrum." }\end{array}$ & Rejection \\
\hline 5 & $\begin{array}{l}\text { Avoidance: avoid because of } \\
\text { controversy }\end{array}$ & $\begin{array}{l}\text { "It seems that evolution really just brings up controversy and arguments about } \\
\text { who's right and who's wrong." }\end{array}$ & Other \\
\hline 6 & $\begin{array}{l}\text { Theory: only a theory with serious } \\
\text { flaws }\end{array}$ & "I believe that evolution is more of a theory than a fact" & Rejection \\
\hline 7 & $\begin{array}{l}\text { Man different: accept evolution } \\
\text { with exception of mankind }\end{array}$ & $\begin{array}{l}\text { "I do know that there is substantial evidence that animals evolve. I do not } \\
\text { believe, however, that humans evolved from apes." }\end{array}$ & $\begin{array}{l}\text { Limited } \\
\quad \text { acceptance }\end{array}$ \\
\hline 8 & Ignorance: do not have an opinion & "For the most part, I just haven't had really any interest into the idea." & Other \\
\hline 9 & $\begin{array}{l}\text { Equivocal: uncertain, some } \\
\text { evidence compelling, some not }\end{array}$ & $\begin{array}{l}\text { "Basically, overall I am unsure how to really feel about evolution because I do not } \\
\text { think that I have received adequate education on both sides of the argument } \\
\text { to date." }\end{array}$ & Other \\
\hline 10 & $\begin{array}{l}\text { Suspended judgment: resolving } \\
\text { the matter not a high priority }\end{array}$ & $\begin{array}{l}\text { "I couldn't care less honestly how we got here because I have full faith in that } \\
\text { God created Earth." }\end{array}$ & Other \\
\hline 11 & $\begin{array}{l}\text { Acceptance: full acceptance of the } \\
\text { theory }\end{array}$ & $\begin{array}{l}\text { "I have been taught evolution from the Darwin perspective and have accepted it } \\
\text { wholeheartedly, despite my religious nature and upbringing." }\end{array}$ & $\begin{array}{l}\text { Full } \\
\quad \text { acceptance }\end{array}$ \\
\hline 12 & $\begin{array}{l}\text { Adaptation only: accept small } \\
\text { changes and adaptation, but } \\
\text { not speciation }\end{array}$ & $\begin{array}{l}\text { "I do believe that microevolution exists, but I don't believe that one species } \\
\text { (humans), can evolve completely from another" }\end{array}$ & $\begin{array}{l}\text { Limited } \\
\text { acceptance }\end{array}$ \\
\hline 13 & $\begin{array}{l}\text { Other: essays that do not fit in any } \\
\text { of the categories above }\end{array}$ & $\begin{array}{l}\text { "Some random and not very sound ideas I have is that we have misinterpreted } \\
\text { the artifacts we have found and the Neanderthals were actually the angel } \\
\text { hybrids talked about in Genesis." }\end{array}$ & Other \\
\hline
\end{tabular}

acceptance of evolution. The total score is the sum of each response on 13 five-point Likert-scale items, for a total of 65 points. The GAENE was administered before and following the intervention. Note that we intentionally did not measure evolution knowledge for three reasons. First, knowledge was not the objective of our study, as we were focused on acceptance only; second, several studies show that knowledge and acceptance are tenuously correlated (for positive and negative examples, see Johnson and Peeples, 1987; Bishop and Anderson 1990; Rutledge and Warden, 2000; Brem et al., 2003; Sinatra et al., 2003; Miller et al., 2006; Nehm and Schonfeld, 2007; Chinsamy and Plagányi, 2008; Hasan and Donnelly, 2011; Hill, 2014; Rissler et al., 2014; Glaze et al., 2015; Dunk et al., 2017; Mead et al., 2017; Weisberg et al., 2018); and third, the surveys were long, and survey fatigue can negatively affect response rate and results. Thus, we do not believe we would gain information relevant to our objective of measuring the effect of a reconciliation module on acceptance by including knowledge instrumentation.

Measure of Religiosity. To determine whether our intervention influenced religiosity of our participants, we measured student religiosity before and following the intervention. The religiosity instrument was taken from a previously validated study (see Manwaring et al., 2015). It consists of 15 items, each on a six-point Likert scale assessing self-reported religious practices (e.g., frequency of prayer), religious influence (e.g., religion's influence on the food you eat), and religious hope (e.g., belief in miracles). Total religiosity was calculated by summing responses to the 15 items for a total possible score of 75 points.

\section{Statistical Analyses}

To determine which demographic factors predicted the preGAENE and change in GAENE, we used multiple linear regression. To compare qualitative essay scores before and after intervention, we used a chi-square goodness of fit to compare the distributions of the four binned categories (full acceptance, limited acceptance, rejection, and other). To quantitatively determine whether acceptance of evolution changed in response to our intervention, we compared pre and post GAENE scores using a paired-samples $t$ test, when assumptions of normality were met, and an exact sign test when nonparametric alternatives were needed within each institution (an exact sign test was used as an alternative to the Wilcoxon signed-rank test due to nonsymmetrical distributions). Mean of normalized gains ( $g$ scores) were calculated to compare the progress at each school (Hake, 1998). Changes in religiosity were assessed, again using paired-samples $t$ tests or exact sign tests within each institution.

\section{RESULTS}

\section{Predicting Evolution Acceptance}

A multiple regression analysis was performed on combined data from all four institutions to predict pre-GAENE scores from a participant's Genesis interpretation and self-reported reaction to evolution in high school. (The following variables were run in an initial regression but were found to be insignificant and were excluded from our final model: age, geographic location in 
TABLE 3. Essay prompt 2 codes

\begin{tabular}{|c|c|c|c|}
\hline Code & Brief description & Example quote & Final coding \\
\hline 1 & Change toward acceptance & $\begin{array}{l}\text { "Similar to the different views that Origins refers to, I would now consider myself a } \\
\text { believer in evolutionary creationism." }\end{array}$ & Full acceptance \\
\hline 2 & $\begin{array}{l}\text { Change toward accep- } \\
\text { tance, with exception } \\
\text { of man }\end{array}$ & $\begin{array}{l}\text { "I still do not believe that humans came from monkeys, but I do believe that } \\
\text { evolution is change that is occurring over time." }\end{array}$ & Limited acceptance \\
\hline 3 & $\begin{array}{l}\text { Change toward confusion } \\
\text { and discomfort }\end{array}$ & $\begin{array}{l}\text { "At the beginning of the semester, I was a lot more passive about evolution. Now I'm } \\
\text { just confused and depending on the day, sometimes I feel like defending it and } \\
\text { sometimes I feel like attacking it." }\end{array}$ & Other \\
\hline 5 & $\begin{array}{l}\text { Change to tolerance of a } \\
\text { different point of view }\end{array}$ & $\begin{array}{l}\text { "So, I suppose that my change in position is that I fall somewhere in the middle of } \\
\text { everything. I do not agree nor disagree." }\end{array}$ & Other \\
\hline 6 & No change, still accept & $\begin{array}{l}\text { "I claim my present point of view as being similar to my earlier one. Evolution is a } \\
\text { real thing and Heavenly Father oversees it." }\end{array}$ & Full acceptance \\
\hline 7 & $\begin{array}{l}\text { No change, still accept, but } \\
\text { not man }\end{array}$ & "I still support evolution for everything that exists except humans" & Limited acceptance \\
\hline 9 & No change, still confused & $\begin{array}{l}\text { "One of the biggest questions is concerning Adam and Eve. According to evolution, } \\
\text { Neanderthals existed before the first "humans" as we know them. What does that } \\
\text { mean? I'm not really sure." }\end{array}$ & Other \\
\hline 10 & Do not care & "Evolution has no significance to me." & Other \\
\hline 11 & $\begin{array}{l}\text { Other (did not fit into any } \\
\text { other category) }\end{array}$ & $\begin{array}{l}\text { "So, to put it simply: I learn evolution, I recite and memorize facts of evolution, I } \\
\text { discuss it with my STEM major friends and I discuss it with my conservative } \\
\text { parents, but I do not wholly and fully know that it is fact." }\end{array}$ & Other \\
\hline 12 & $\begin{array}{l}\text { Still accept, but received } \\
\text { substantial evidence to } \\
\text { support acceptance }\end{array}$ & $\begin{array}{l}\text { "Before this semester I was a firm believer in evolution. However, this semester has } \\
\text { given me a broader and more extensive knowledge of the evidence supporting } \\
\text { this theory." }\end{array}$ & Full acceptance \\
\hline 13 & $\begin{array}{l}\text { Change toward accep- } \\
\text { tance, adaptation only } \\
\text { (microevolution) }\end{array}$ & $\begin{array}{l}\text { "As I have gained more knowledge on the different types of evolution, I have come to } \\
\text { agree with microevolution, for it consists of small changes, and no new kinds are } \\
\text { developed." }\end{array}$ & Limited acceptance \\
\hline
\end{tabular}

childhood, gender, religious affiliation, chosen major [STEM or non-STEM], whether a student received public or private schooling in high school, the extent to which evolution was covered in a student's high school, and institution.) All assumptions for linear regression were tested and met. Our model significantly predicted pre-GAENE scores, $F(2,186)=40.14, p<0.001$. The $R^{2}$ for the overall model was $30.1 \%$ with an adjusted $R^{2}$ of $29.4 \%$. Interpretations of coefficients (see Table 4) show that for every step toward figurative interpretation of Genesis (e.g., from literal to semiliteral or from semiliteral to figurative), student scores on the pre-GAENE went up by 4.2 points (on a 65-point scale), holding high school acceptance constant. In addition, with each step toward full acceptance in a student's self-reported

TABLE 4. Multiple regression analysis showing the prediction of pre-GAENE scores by a participant's interpretation of Genesis and reaction to evolution in high school ${ }^{\mathrm{a}}$

\begin{tabular}{lrrrl}
\hline Variable & $\boldsymbol{B}$ & $\mathrm{SE}_{\boldsymbol{B}}$ & $\boldsymbol{b}$ & $\boldsymbol{p}$ value \\
\hline Intercept & 27.64 & 2.85 & & $<0.001$ \\
Genesis interpretation & 4.20 & 0.87 & 0.31 & $<0.001$ \\
High school reaction & 2.46 & 0.41 & 0.38 & $<0.001$ \\
\hline
\end{tabular}

${ }^{\mathrm{a}} B=$ unstandardized regression coefficient; $\mathrm{SE}_{B}=$ standard error of the coefficient; $b=$ standardized coefficient. reaction to evolution in high school (e.g., from mild conflict to neutral or from neutral to accept) the pre-GAENE score increased by 2.46 points, holding Genesis interpretation constant.

A second analysis was run to predict a change in acceptance via a change in GAENE scores after intervention. None of the measured variables were significant predictors of change, $p>$ 0.05. Again, all assumptions were met for linear regressions.

\section{Change in Evolution Acceptance}

Essays. Based on essay responses, providing students with a compatibility module appears to significantly increase evolution acceptance. At BYU, students showed a significant shift in distribution of essay codes $\left(\chi^{2}(3)=54.55, p<0.001\right)$ toward acceptance. Before having the compatibility module administered, $38.5 \%$ of students accepted all components of evolutionary theory. After the module, full acceptance jumped to $70.1 \%$, a $31.6 \%$ increase.

PLNU and CCU showed similar significant shifts in acceptance (PLNU: $\chi^{2}(3)=24.69, p<0.001$, CCU: $\chi^{2}(3)=40.22, p<$ 0.001). At PLNU, students went from an initial percentage of full acceptance of $51 \%$ to a postcourse full acceptance of $83.1 \%$, a $32.1 \%$ increase. At CCU, $13.0 \%$ of students fully accepted evolution at the start of the semester compared with $43.5 \%$ at the end of the semester, a $30.5 \%$ increase. 


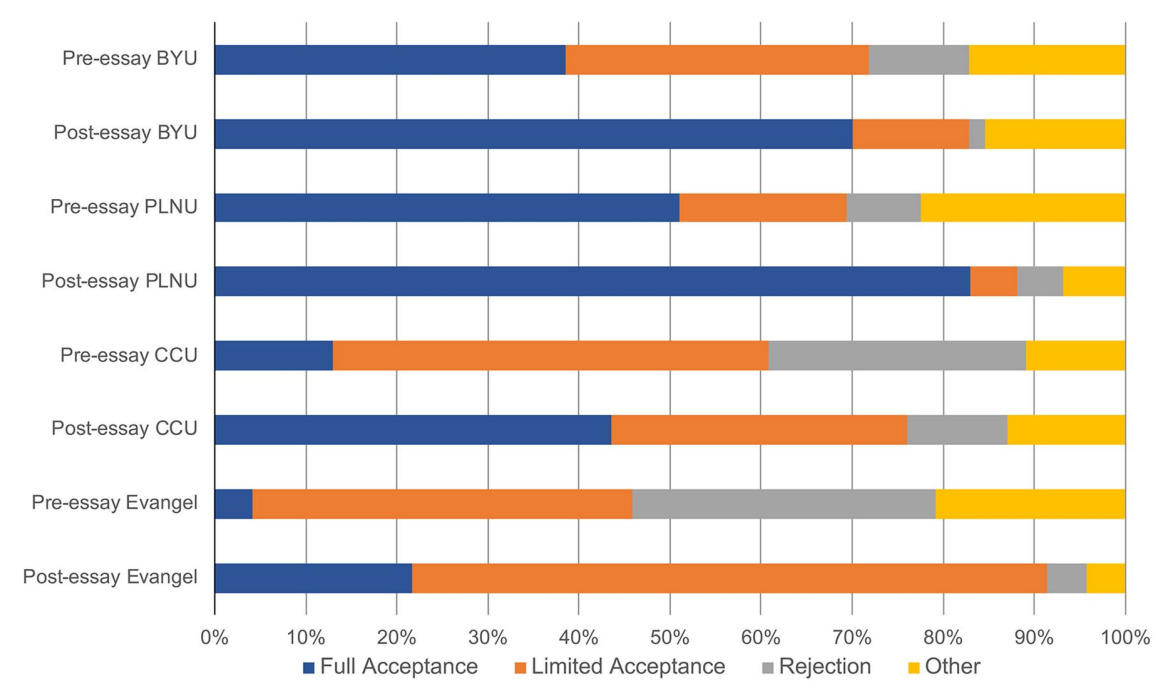

FIGURE 1. Pre and post essay distributions at each institution. Horizontal stacked bars indicate the proportion of essays that fell into each of the broad categories before (pre = prompt 1) and after (post = prompt 2) intervention. "Full Acceptance" refers to any response in which the student expressed an acceptance of evolution with no indication of any rejection of individual components (e.g., human evolution). "Limited Acceptance" refers to any response in which the student acknowledged that evolution occurs but took specific issue with one or more components of the theory (most common components included human origins and speciation events or macroevolution). "Rejection" refers to any response in which the student denied the validity of evolution. Other refers to any response that could not be categorized into any of the first three. showed limited acceptance. After the module, however, limited acceptance jumped to $69.6 \%$, a $27.9 \%$ increase, and rejection dropped to $4.3 \%$ (one student; see Figure $1)$.

GAENE. We analyzed the GAENE to quantitatively measure any changes over the course of the semester in student acceptance of evolution. The average preGAENE for BYU students was 70.3\%, and $80.8 \%$ on the post-GAENE. This showed a $10 \%$ increase over the course of the semester $(t(74)=9.006, p<0.001)$. We saw similar results at PLNU and EU. The pre-GAENE showed that the average score for PLNU students at the beginning of the semester was $72.5 \%$. The post-GAENE for PLNU was $84.0 \%$. This shows an $11.5 \%$ increase over the course of the semester $(t(58)=8.26, p<0.001)$. At EU, the preGAENE was $60.3 \%$ and the post-GAENE was $68.6 \%$, showing an $8 \%$ increase $(t(22)=3.268, p=0.004)$. Owing to low response rates, CCU was not included in analysis (see Figure 2). Normalized gains are as follows: $33.5 \%$ at BYU, $42.0 \%$ at PLNU, and $16.9 \%$ at EU.
At EU, the results were less dramatic, but still significant, $\left(\chi^{2}(3)=29.91, p<0.001\right)$, showing an increase of $17.5 \%$ in full evolution acceptance. However, the most striking aspect at EU is that there was a $29 \%$ decrease in evolution rejection. Many of the students who originally rejected evolution were able to at least make the jump to limited acceptance. Before the module, 33.3\% of students rejected evolution, while $20.8 \%$ fell into the "other" category (i.e., no opinion). Meanwhile, $41.7 \%$ of students

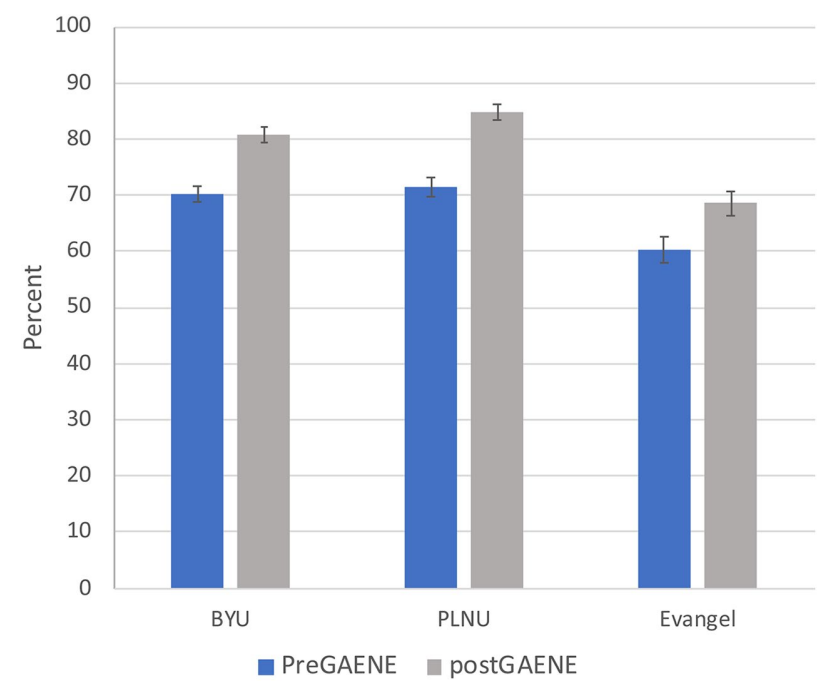

FIGURE 2. Pre- and post-GAENE scores at each institution. The GAENE is scored on a 65-point scale; numbers have been converted to percentages. Error bars represent the standard error of the mean.

\section{Religiosity}

To determine whether our intervention affected student religiosity, we compared students' self-reported religiosity at the end of the intervention with that reported at the beginning, measured on a 75-point scale. We found no significant changes in religiosity across all denominations that collected pre and post data. Before the administration of the intervention, BYU had a religiosity of 70.8. After the reconciliation module was given to students, religiosity remained relatively consistent at 71.3 (an exact sign test showed no median differences between pre $[$ median $=72.0]$ and post $[$ median $=74.0], p=0.078)$. A post religiosity score was not collected at PLNU; their average pre score was 59.3. At EU, religiosity went from 65.1 to 63.1 (an exact sign test showed no median differences between pre and post [median for both $=65.0$ ], $p=0.832$; see Figure 3 ).

\section{DISCUSSION}

Based on these results, providing students with a reconciliation module alongside evolution instruction significantly increased evolution acceptance. Their acceptance levels as they enter the classroom appear to be influenced by their interpretation of biblical Genesis and their impressions of evolution in high school. Regardless of their acceptance as they enter, based on our hypothesis that providing students with a way to reconcile faith and science can positively influence acceptance, we predicted a significant increase in acceptance following our intervention, a prediction confirmed by our results $(p<0.001)$. Students at BYU, PLNU, and CCU each showed a shift of more than $30 \%$ toward full acceptance, while EU only showed a shift of $17.5 \%$ toward full acceptance but a $46 \%$ shift to partial acceptance (Figure 1 shows essay data). Therefore, providing 


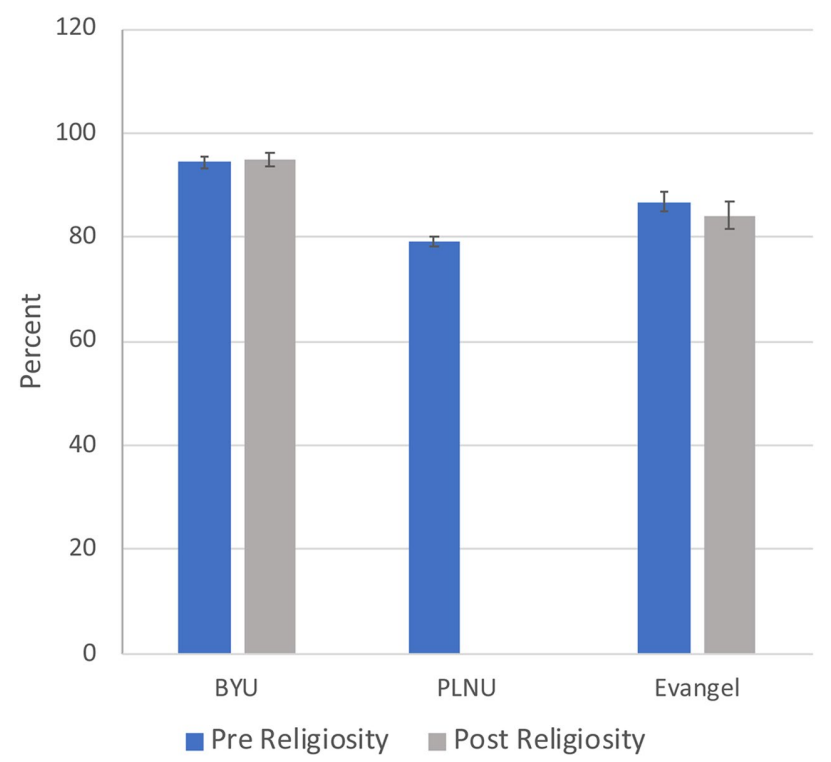

FIGURE 3. Pre and post religiosity at each institution. Religiosity is measured on a 75-point scale. Scores have been left raw. Error bars represent the standard error of the mean.

students with paths to compatibility can significantly increase acceptance of evolution regardless of their starting points.

Additionally, evolution rejection decreased in all of the tested schools. Students at EU were the most striking example, with an initial rejection of evolution at $33.33 \%$ and a post model rejection at $4.3 \%$ (one student), a $29 \%$ decrease (Figure 1 shows essay data). Similarly, students at BYU, PLNU, and CCU showed significant $9.4 \%, 3.1 \%$, and $23.3 \%$ decreases in evolution rejection, respectively. Thus, our reconciliation module appears not only to increase full acceptance rates, but it also decreases rejection in favor of accepting at least parts of the theory.

An interesting trend was found in the outlying case of EU students. In terms of limited acceptance of evolution, numbers dropped at BYU, PLNU, and CCU by $20.5 \%, 13.3 \%$, and $33.3 \%$, respectively (Figure 1). Therefore, we reasonably assumed that many of these students made the leap to full acceptance post model, and therefore limited acceptance numbers decreased. However, this trend did not prove true at EU, where initial limited acceptance of evolution was $41.7 \%$, but post-model limited acceptance increased to $69.6 \%$, a $27.9 \%$ increase. As stated previously, evolution rejection decreased at EU by $29.03 \%$. With a $27.9 \%$ increase in limited evolution acceptance, it can be reasonably assumed these students who initially rejected evolution made the leap to at least limited acceptance, if not full. Therefore, although the increase in full acceptance was not as large as at the other institutions, progress was still made. Also notable is that this limited acceptance includes ideas such as evolutionary adaptation and natural selection, which may be useful in making informed decisions about antibiotic usage, conservation efforts, vaccine usage, and other topics informed by evolutionary thinking. Thus, although not a full acceptance of evolution, our intervention has helped students accept valuable principles related to many practical applications of evolution.

Our results also showed that, over the course of the semester, as students increased in acceptance of evolution, their religiosity was not affected (Figure 3). Students were able to reconcile their religious beliefs with evolution. Barnes and Brownell (2017) call on scientists and science instructors to bridge gaps between religious and secular views by incorporating ReCCEE practices in their classrooms and other public settings. This is with the hope that we can increase overall student acceptance of evolution and decrease conflict between religion and evolution.

It is important to note that the effectiveness of the reconciliation module varies with the delivery given by the professor. At BYU and PLNU (which had 10 and 13\% increases from pre- to post-GAENE, respectively), the professors presented theistic evolution in a very favorable manner, prompting students to reconcile evolution with their religious beliefs. All the scientific evidence for evolution was presented agnostically. At EU, which increased only $8 \%$, the professor presented detailed information about five competing origins perspectives (YEC, OEC, theistic evolution, agnostic evolution, and atheistic evolution). Students identified the strengths and weaknesses of each view posited by proponents and detractors. While it was made clear that Christian faith was incompatible with atheism, students were left to decide for themselves which view to embrace. This was followed by standard college textbook material on evolution.

Additionally, because students probably choose to attend universities that are compatible with their worldviews and values, religiously conservative schools are populated by more religiously conservative students than other schools. These universities may also be affiliated with conservative religious groups (e.g., Assemblies of God). As stated previously, EU is affiliated with the Assemblies of God, a Pentecostal Christian denomination. Assemblies of God adherents typically have a more conservative view in interpreting and applying scriptures compared with the Church of the Nazarene (PLNU) or the Church of Jesus Christ of Latter-day Saints (BYU). Students who affiliate with the Assemblies of God may find it harder to reconcile faith and evolution than PLNU and BYU students. While it does not appear that religiosity is affected by acceptance of evolutionary theory, the reverse is very likely. That is, religiously conservative people are likely more resistant to evolution acceptance than others (Dagher and BouJaoude, 1997; Hill, 2014). Schools located in regions of the United States whose populations are more resistant to evolution, like the South (Rissler et al., 2014), will naturally be composed of students with this viewpoint. This may be the case for EU, which draws most of its students from Missouri, and may partially explain the lower evolution acceptance rates found in the EU student population.

\section{Broader Connections}

Research shows that evolution acceptance in the United States is lower than in 32 European nations (Miller et al., 2006). Researchers and scientists have attempted to address this discrepancy through various teaching strategies. These strategies have been predicated upon finding which factors most greatly influence evolution acceptance. Many researchers have suggested potential factors as being influential, such as an understanding of the nature of science (Cavallo and McCall, 2008; Cofré et al., 2017; Dunk et al., 2017), student knowledge of evolutionary theory (Rissler et al., 2014; Glaze et al., 2015; Weisberg et al., 2018), reasoning ability (Lawson and Weser, 
1990; Honey, 2015; although see Manwaring et al., 2018), and individual religiosity (Dagher and BouJaoude, 1997; Hill, 2014; Rissler et al., 2014). Research is mixed on the effectiveness of each of these approaches. Our findings oppose those of Coyne (2012), however, who contended that the only way to increase evolution acceptance is for individuals to completely abandon their religiosity.

It is also interesting to consider that the way in which students interpret Genesis and the impressions they get during high school coverage of the subject are influential factors in acceptance as they enter a college course. This would suggest that perhaps this reconciliatory approach should start earlier in a student's exposure to the subject, that is, in the high school setting. It is unlikely, however, that any one of these approaches can completely mitigate the lack of evolution acceptance in the United States. Nevertheless, we have argued that an individual can maintain religiosity and increase evolution acceptance if the subject is approached in a way that suggests potential compatibility. We add our findings to other recent research (Barnes and Brownell, 2017) that emphasizes a more culturally/religiously conscious approach to teaching evolution. We have shown that, with a reconciliatory approach that focuses on acceptance of evolution, we do not diminish religiosity.

\section{Limitations}

Despite the significant results of our study, we recognize that there are potential limiting factors when administering this model. One such factor is the influence of a role model. Research has shown that the influence of a religious, evolution-accepting role model can play a significant factor in whether a student will accept evolution (e.g., Barnes and Brownell, 2017; Holt et al., 2018). Given that the majority of biologists are not religious (Graffin and Provine, 2007), having a role model who models religious and scientific commitment to students may prove to be difficult in some situations. There are, however, resources that can assist students in finding role models outside the classroom (e.g., the Smithsonian's Human Origins Broader Social Impacts Committee provides videos from scientists of diverse religious backgrounds to help students navigate faith and science; Smithsonian, 2019). The presentation of these resources to religiously minded students by culturally sensitive nonreligious educators may provide a model to enhance acceptance of evolution.

Another limitation is our intentional decision not to measure evolution knowledge or nature of science knowledge. As previously stated, this was not the objective of the current study. However, it is certainly possible (and likely probable, given the literature) that increased knowledge and understanding of the nature of science acquired during the course of the semester were additional contributors to the increase in students' acceptance of evolution. We are certainly not claiming that the reconciliation modules were the only causal factor for gains in acceptance. However, the gains that we saw in this study are large in comparison to what is in the literature, suggesting that the reconciliation approach is likely a large contributing factor. Further research on these two variables is warranted.

\section{CONCLUSION}

As demonstrated in this study, religious students demonstrate gains in evolution acceptance when offered a reconciliation module. Going forward, this has major implications for science education. Educators, as they become willing and able to administer such models, will have a greater opportunity to relate to students and create a safe learning environment. Religious students will not feel as much tension exploring scientific fields and data from a perspective built on the nature of science. Thus, it is possible that more individuals will be interested in scientific discovery and can make greater contributions to the scientific endeavor.

Additionally, we argue that many of the stumbling blocks surrounding faith and evolution can eventually be overcome. With a promising method of reconciling science and religion, co-existence of these ideas can be established. The current director of National Institutes of Health, Francis Collins, captures this nicely: "One of the great tragedies of our time is this impression that has been created that science and religion have to be at war" (Swinford, 2006). Our findings demonstrate that they do not.

\section{ACKNOWLEDGMENTS}

Work presented in this article was supported by the Howard Hughes Medical Institute. We are grateful for its support of this important work.

\section{REFERENCES}

Alles, D. L. (2001). Using evolution as the framework for teaching biology. American Biology Teacher, 63, 20-23.

Badger, S., \& Tenneson, M. (2014). Christian perspectives on origins (3rd ed. rev.). Springfield, MO: Evangel University.

Baker, J. O. (2013). Acceptance of evolution and support for teaching creationism in public schools: The conditional impact of educational attainment. Journal for the Scientific Study of Religion, 52, 216-228.

Barnes, M. E., \& Brownell, S. E. (2017). A call to use cultural competence when teaching evolution to religious college students: Introducing religious cultural competence in evolution education (ReCCEE). CBE-Life Sciences Education, 16, es4

Berkman, M., \& Plutzer, E. (2010). Evolution, creationism, and the battle to control America's classrooms. New York: Cambridge University Press.

Bishop, B. A., \& Anderson, C. W. (1990). Student conceptions of natural selection and its role in evolution. Journal of Research in Science Teaching. $27,417-425$

Bradshaw, W. S., Phillips, A. J., Bybee, S. M., Gill, R. A., Peck, S. L., \& Jensen, J. L. (2018). A longitudinal study of attitudes toward evolution among undergraduates who are members of the Church of Jesus Christ of Latter-day Saints. PLoS One, 13, e0205798. https://doi.org/10.1371/ journal.pone.0205798

Brem, S. K., Ranney, M., \& Schindel, J. (2003). Perceived consequences of evolution: College students perceive negative personal and social impact in evolutionary theory. Science Education, 87, 181-206.

Cavallo, A. M. L., \& McCall, D. (2008). Seeing may not mean believing: Examining students' understandings and beliefs in evolution. American Biology Teacher, 70, 522-530.

Cherif, A., Adams, G., \& Loeher, J. (2001). What on "earth" is evolution? The geological perspective on teaching evolutionary biology effectively. American Biology Teacher, 63, 576-591.

Chinsamy, A., \& Plagányi, É (2008). Accepting evolution. Evolution, 62 $248-254$

Cofré, H., Cuevas, E., \& Becerra, B. (2017). The relationship between biology teachers' understanding of the nature of science and the understanding and acceptance of the theory of evolution. International Journal of Science Education, 39, 2243-2260.

Coyne, J. A. (2012). Science, religion, and society: The problem of evolution in America. Evolution, 66, 2654-2663.

Dagher, Z. R., \& BouJaoude, S. (1997). Scientific views and religious beliefs of college students: The case of biological evolution. Journal of Research in Science Teaching, 34, 429-445. 
Dawkins, R. (1989). Book review of Donald Johanson and Maitland Edey's Blueprint. New York Times, section 7, 34.

Dawkins, R. (2008). The God delusion. New York: Mariner Books.

Deniz, H., Donnelly, L. A., \& Yilmaz, I. (2007). Exploring the factors related to acceptance of evolutionary theory among Turkish preservice biology teachers: Toward a more informative conceptual ecology for biological evolution. Journal of Research in Science Teaching, 45, 420-443.

Dunk, R., Petto, A., Wiles, J., \& Campbell, B. (2017). A multifactorial analysis of acceptance of evolution. Evolution: Education \& Outreach, 10I, 1-8.

Evenson, W. E., \& Jeffery, D. E. (2005). Mormonism and evolution: The authoritative LDS statements. Salt Lake City, UT: Greg Kofford Books.

Farber, P. (2003). Teaching evolution and the nature of science. American Biology Teacher, 65, 347-354.

Gallup. (2017). In US, belief in creationist view of humans at new low. Retrieved April 10, 2019, from www.gallup.com/poll/210956/belief -creationist-view-humans-new-low.aspx

Glaze, A. L., Goldston, M. J., \& Dantzler, J. (2015). Evolution in the southern USA: Factors influencing acceptance and rejection in pre-service science teachers. International Journal of Science and Math Education, 13, 11891209.

Gould, S. J. (1997). Nonoverlapping magisteria. Natural History, 106, 16-22.

Graffin, G. W., \& Provine, W. B. (2007). Macroscope: Evolution, religion and free will. American Scientist, 95, 294-297.

Haarsma, D. B., \& Haarsma, L. D. (2011). Origins: Christian perspectives on creation, evolution, and intelligent design. Grand Rapids, MI: Faith Alive Christian Resources.

Hake, R. R. (1998). Interactive-engagement vs. traditional methods: A six thousand student survey of mechanics test data for introductory physics courses. American Journal of Physics, 66, 64-67

Hall, G. E., \& Woika, S. A. (2018). The fight to keep evolution out of schools: The law and classroom instruction. American Biology Teacher, 80, 235-239.

Hasan, D., \& Donnelly, L. (2011). Preservice secondary science teachers' acceptance of evolutionary theory and factors related to acceptance. Reports of the National Center for Science Education, 31(4), 2.1-2.8

Hill, J. P. (2014). Rejecting evolution: The role of religion, education, and social networks. Journal for the Scientific Study of Religion, 53, 575-594.

Holt, E. A., Ogden, T. H., \& Durham, S. L. (2018). The positive effect of role models in evolution instruction. Evolution: Education \& Outreach, 11, 11

Honey, L. P. (2015). Why I teach the controversy: Using creationism to teach critical thinking. Frontiers in Psychology, 6, 793.

Johnson, R. L., \& Peeples, E. E. (1987). The role of scientific understanding in college: Student acceptance of evolution. American Biology Teacher, 49, 93-96.

Lamoureux, D. O. (2008). Evolutionary creation: A Christian approach to evolution. Eugene, OR: Wipf and Stock.

Lawson, A. E., \& Weser, J. (1990). The rejection of nonscientific beliefs about life: Effects of instruction and reasoning skills. Journal of Research in Science Teaching, 27, 589-606

Legare, C. H., Lane, J. D., \& Evans, E. M. (2013). Anthropomorphizing science: How does it affect the development of evolutionary concepts? Merrill-Palmer Quarterly, 599, 168-197

Manwaring, K. F., Jensen, J. L., Gill, R. A., \& Bybee, S. M. (2015). Influencing highly religious undergraduate perceptions of evolution: Mormons as a case study. Evolution: Education and Outreach, 8, 1-12.

Manwaring, K. F., Jensen, J. L., Gill, R. A., Sudweeks, R. R., Davies, R. S., \& Bybee, S. M. (2018). Scientific reasoning ability does not predict scientific views on evolution among religious individuals. Evolution: Education $\&$ Outreach, 11, 2

Mead, R., Hejmadi, M., \& Hurst, L. D. (2017). Teaching genetics prior to teaching evolution improves evolution understanding but not acceptance. PLOS Biology, 15, 388-394.
Miller, J. D., Scott, E. C., \& Okamoto, S. (2006). Public acceptance of evolution. Science, 313, 765.

National Center for Science Education. (2019). The creation/evolution continuum. Retrieved July 1, 2019, from https://ncse.com/library-resource/ creationevolution-continuum

Nehm, R., \& Schonfeld, I. S. (2007). Does increasing biology teacher knowledge of evolution and the nature of science lead to greater preference for the teaching of evolution in schools? Journal of Science Teacher Education, 18, 699-723

PBS. (2007). Bill Moyers talks with E. O. Wilson. Bill Moyers Journal. Retrieved April 10, 2019, from www.pbs.org/moyers/journal/07062007/transcript1 html

Pew Research Center. (2014). 2014 Religious landscape study. Retrieved April 10, 2019, from www.pewforum.org/religious-landscape-study

Pew Research Center. (2016). Religious belief and national belonging in Central and Eastern Europe. Retrieved April 10, 2019, from www.pewforum .org/2017/05/10/science-and-religion

Pew Research Center. (2017). Key findings about Americans' belief in God Retrieved April 10, 2019, from www.pewresearch.org/fact-tank/2018/ 04/25/key-findings-about-americans-belief-in-god

Rissler, L., Duncan, S., \& Caruso, N. (2014). The relative importance of religion and education on university students' views of evolution in the Deep South and state science standards across the United States. Evolution: Education \& Outreach, 7, 1-17.

Rutledge, M. L., \& Warden, M. A. (2000). Science and high school biology teachers: Critical relationships. American Biology Teacher, 62, 23-31.

Sinatra, G. M., Southerland, S. A., McConaughy, F., \& Demastes, J. W. (2003) Intentions and beliefs in students' understanding and acceptance of biologic evolution. Journal of Research in Science Teaching, 40, 510-528.

Smith, M. U., Snyder, S. W., \& Devereaux, R. S. (2016). The GAENE-Generalized Acceptance of EvolutioN Evaluation: Development of a new measure of evolution acceptance. Journal of Research in Science Teaching, 53, 1289-1315.

Smithsonian. (2019). Thoughts on science, religion, and human origins Retrieved April 10, 2019, from http://humanorigins.si.edu/about/broader -social-impacts-committee/thoughts-science-religion-and-human - origins

Swinford, S. (2006). LONDON: I've found God, says man who cracked the genome. VirtueOnline. Retrieved April 10, 2019, from www.virtueonline .org/london-ive-found-god-says-man-who-cracked-genome

Taylor, J. (2019). The new atheists. Internet encyclopedia of philosophy Retrieved July 1, 2019, from www.iep.utm.edu/n-atheis/

Tenneson, M., \& Badger, S. (2010, Spring). A brief overview of Pentecostal views on origins. Enrichment Journal (online edition). Retrieved April 10 2019, from http://enrichmentjournal.ag.org/201002/ejonline_201002 _origins.cfm

Weisberg, D. S., Landrum, A. R., Mertz, S. E., \& Weisberg, M. (2018). No missing link: Knowledge predicts acceptance of evolution in the United States. BioScience, 68, 212-222.

What does the church believe about evolution? (2016). New Era, October, 41

Winslow, M. W., Staver, J. R., \& Scharmann, L. C. (2011). Evolution and personal religious belief: Christian university biology-related majors' search for reconciliation. Journal of Research in Science Teaching, 48, 1026-1049.

Yerky, M. D., \& Wilczynski, C. J. (2014). The mystery of the skulls: What can old bones tell us about hominin evolution? American Biology Teacher, 76, 109-117

YouGov. (2017). Science and religion: Exploring the spectrum. Retrieved April 10, 2019, from www.google.com/url?q=https://docs.google.com/ viewerng/viewer? url\%3Dhttps://sciencereligionspectrum.org/wp -content/uploads/2017/09/SRESYouGov-survey-preliminary-findings -5.9.17.pdf\%26hl\%3Den_GB\&sa=D\&ust=1554847443513000\&usg =AFQjCNE8zmLbvGaH-xrskiBNRI9AUFP_hg 